\title{
Evaluation of the Cittaslow Administrators to the Process of Cittaslow Participation and Sustainability*
}

\author{
Sakin Șehir Yöneticilerinin Sakin Șehir Bașvuru Süreci ve Sürdürüllebilirliğe \\ Yönelik Değerlendirmeleri
}

\author{
Res. Asst. Sema Ekincek - Asst. Prof. Dr. Emre Ozan Aksöz
}

\begin{abstract}
Cittaslow Movement has developed rapidly around the world in recent years. Cittaslow movement is turning into an important tool for our cities to become sustainable destinations. In this context, cittaslow administrators, who are coordinators and stakeholders in the expansion of the movement, have great importance for the spread of the cittaslow movement and for its sustainability. The aim of this study is to reveal the assessments of cittaslow administrators regarding the destination and cittaslows in terms of cittaslows' objectives, criteria, involvement process and sustainability by putting forth their profiles. The further aim of this study is to evaluate the factors prominent in the process of participation in the cittaslow movement, aspiring to conserve the original identity of the cities and to develop them in terms of the cittaslows' administrators. In this study, by taking the opinions of the administrators in the process of their participation, supplying the compulsory conditions which are required and revealing the contributions which the movement will make, identifying the similarities and the differences between the administrators has been aimed. In the study, as a data collection tool, the questionnaire technique was used. Within the scope of the study, the data collection instrument was developed in line with the related literature and with expert opinions. The population of this study included directors of cittaslows. The questionnaires were applied to all Cittaslow administrators (167 administrators), and the feedback was returned from
\end{abstract}

70 administrators. In addition to the descriptive statistics; Mann-Whitney $U$ and Kruskal-Wallis H tests were used for the analysis of the obtained data, and the profiles of cittaslow administrators were determined. The objectives of cittaslows were classified according to their severity, and their criteria were classified in accordance with their degree of difficulty by the administrators. Evaluation of administrators regarding involvement in cittaslow movement was identified, and contribution of cittaslows to sustainability and the sustainability of the destination were evaluated by the directors. Finally, the conclusions and the implications were discussed in detail on the basis of the research findings. In addition, the contributions of the study to the literature were mentioned, and related suggestions were put forward to develop cittaslow movement.

Keywords: Cittaslow, sustainability, the process of participation in cittaslow movement, the administrator of cittaslow

\section{Öz}

Dünyada hızla gelişen sakin şehir hareketi, son yıllarda Türkiye'de de gelişim göstermeye başlamıştır. Bu hareket, şehirlerimizin sürdürülebilir destinasyonlar haline gelmesinde önemli bir araç haline dönüşmektedir. Bu bağlamda, sakin şehir hareketinin yaylmasında hare-

\footnotetext{
Res. Asst. Sema Ekincek, Anadolu University Faculty of Tourism, semaekincek@anadolu.edu.tr Asst. Prof. Dr. Emre Ozan Aksöz, Anadolu University Faculty of Tourism, ozana@anadolu.edu.tr

* This study is derived from the master thesis called "The Evaluation of Cittaslow Directors on Cittaslow Movement" which is accepted by Institute of Anadolu University Social Sciences, Department of Tourism and Hotel Management. Project Number: 1303E053
} 
ketin paydaşı ve yürütücüsü olan sakin şehir yöneticileri büyük önem arz etmektedir. Buradan yola çıkarak çalışma, sakin şehir yöneticilerinin profillerinin yan sıra; sakin şehirlerin amaçlarına, kriterlerine, katılım sürecine ve sürdürülebilirlik açısından destinasyona ve sakin şehirlere yönelik değerlendirmelerini ortaya koymayı amaçlamaktadır.

Çalışmanın diğer bir amacı, şehirlerin özgün kimliklerini koruyan ve geliştirmeyi amaçlayan sakin şehir hareketine katılım sürecinde öne çıkan unsurları sakin şehir yöneticileri açısından değerlendirmektir. Çalışmada, sakin şehir yöneticilerinin görüşlerine başvurarak, harekete katılim aşamasinda, gereken zorunlu koşulları sağlamada ve hareketin gelecekte yaratacağı katkıları ortaya koymada yöneticilerin algiları arasinda benzerlikleri ve farklılıkları belirlemek hedeflenmiștir.

Çalışmada, veri toplama aracı olarak anket (soru formu) kullanılmıştır. Çalışma kapsamında alanyazın taraması ve uzman görüşleri alınarak soru formu geliştirilmiştir. Çalıșma evrenini sakin șehir yöneticileri oluşturmaktadır. Calıșmada kullanılan soru formu evrenin tamamına (167 yönetici) ulaștırılmış, 70 yöneticiden geri dönüş alınmıştır. Verilerin analizinde tanımlayıc istatistiklerin yan stra Mann Whitney $U$ ve Kruskal Wallis $H$ testlerinden faydalanılmıştır. Elde edilen bulgular doğrultusunda sakin şehir yöneticilerinin profilleri tespit edilmiş, sakin şehirlerin amaçları önem derecesine göre, kriterleri ise zorluk derecesine göre yöneticiler tarafından sinıflandırılmış, sakin şehir hareketine katılım süreci, sakin şehirlerin sürdürülebilirliğe ve destinasyonun sürdürülebilirliğine olan katklsl yöneticiler tarafından değerlendirilmiştir. Çalışma, alanyazına katkı sağlamanın yanında sakin şehir olmaya aday yöneticilere de öneriler getirmeyi amaçlamıştır.

Anahtar Kelimeler: Sakin Şehir, Sürdürülebilirlik, Sakin Şehir Katılım Süreci, Sakin Şehir Yöneticileri

\section{Introduction}

Cittaslow is a movement of city union which has resulted from the slow food movement to prevent globalization from standardizing the cities' texture, calmness and life style and to hinder removal of their locality (Petrini, 2003). Besides this definition, the contribution of the cittaslow is considered to be important since it reveals the necessity of the sustainability of touristic cities in environmental, financial and social aspects so that they can meet the needs of the future generations (Kozak and Aksöz, 2012). Today's tourists, who are more conscious, pay attention to the originality of the touristic cities which they visit. Therefore, the touristic cities which can not keep sustainable development, diversify the attractiveness, evaluate the sources efficiently, perform new and creative marketing activities, and are obliged to lose their market share in the international market (Özdemir, 2008, s. 6-12).

The sustainability has become important in the touristic cities as well as in every field. The cittaslow conception, which has come out as a sustainable evaluation movement keeping the original identity of the cities, is defined as a local development model. Cittaslow fights with the negativeness brought about by globalization and aims at preventing the negativeness caused by rapid formation in cities due to globalization and at preserving local culture and localness. It contributes to tourism by making the touristic cities sustainable, by enhancing the life quality of local people, and by providing an alternative life style to the local people. For this purpose, the number of the cities willing to participate in the cittaslow movement increases day by day. When considered from this point of view, the process of application to this movement and the criteria which have to be carried out by the administrators are the subjects of this study.

When the studies conducted on the cittaslow movement are examined, it is seen that there are not enough studies to determine the contribution of the cittaslow to the sustainability, the accession process of cittaslow and cittaslow criteria. The study is considered to be important in terms of asserting a relationship between with the sustainability and cittaslow and thereby contributing to the literature and creating the basis for similar studies to be conducted later. This study aims at presenting a profile of the cittaslow administrators, the opinions related to perceptions of the administrators, application process to cittaslow, sustainability and participation in Cittaslow. 


\section{Literature Review}

\section{The Criteria for Cittaslow}

The cittaslows are the cities which prefer to enhance the life quality of their own people. In 1999, with the initiation of Paolo Saturnini, the mayor of Greve in Chianti province in Italy and with the supports of the mayors of Bra (Francesca Guida), Orvieto (Stefano Cimicchi) and Positano (Domenico Marrone) and Carlo Petrini, the founder of Slowfood movement, some Europe cities and municipalities formed a network aiming at decreasing the fast life rhythm (Radstörm, 2011, s.91). These four mayors determined some criteria by holding some interviews. These interviews covered working in quieter and less polluted places, saving the regional esthetical tradition, regional handcrafts, and regional cuisine (Sezgin and Ünüvar, 2011, s.128). They made a decision about sharing each other's experiences in the name of presenting better living conditions to their citizens, creating healthier environments in searching administrative solutions, and in implementing the decisions, using the technology at top level (Sezgin and Ünüvar, 2011, s.128). These ideas led to a 59-item list to be formed. Within this philosophy, a city should present the following criteria for being a cittaslow (Miele, 2008; Yurtseven, 2010; Cittaslow Charter, 2013). These are;

1. Environmental Policies

\section{Infrastructure Policies}

3. Technologies and facilities for urban quality

4. Safeguarding autochthonous production

5. Hospitality

6. Awareness

7. Extraordinary requisites

- Support to Slow Food activities and projects

Table 1. Distribution of Cittaslow Members by countries (December 2015)

\begin{tabular}{ll}
\hline COUNTRY & NUMBERS \\
\hline Italy & 80 cities \\
\hline Poland & 23 cities \\
\hline Germany & 13 cities \\
\hline South Korea & 11 cities \\
\hline Turkey & 10 cities \\
\hline France & 8 cities \\
\hline Netherlands & 8 cities \\
\hline Portugal & 6 cities \\
\hline Belgium & 6 cities \\
\hline Spain & 5 cities \\
\hline Great Britain & 5 cities \\
\hline Norway & 4 cities \\
\hline China & 4 cities \\
\hline Austria & 3 cities \\
\hline Australia & 3 cities \\
\hline USA & 2 cities \\
\hline Canada & 2 cities \\
\hline Denmark & 2 cities \\
\hline Turkish Republic of Northern Cyprus & 2 cities \\
\hline Hungary & 1 city \\
\hline New Zealand & 1 city \\
\hline Ireland & 1 city \\
\hline Switzerland & 1 city \\
\hline Iceland & 1 city \\
\hline South Africa & 1 city \\
\hline Japan & 1 city \\
\hline Finland & 1 city \\
\hline Sweden & 1 city \\
\hline Taiwan & 1 city \\
\hline Cource: www.cittaslow.org & 1 city \\
\hline
\end{tabular}


To be a cittaslow, the population of the city or town should not be more than 50.000 . The meeting of the cittaslow movement was first done in 1999 in Orvieto. The movement which has spread over most cities since 1999 is also known in Turkey with Seferihisar's being a cittaslow. As of the year of 2013, when the data were gathered, there were 167 cittaslows, 9 of which are in Turkey. 208 cities present in 30 countries in the world in 2015. In table 1 shows the distribution by countries.

\section{The Application Process}

Before being cittaslow, the cities must be evaluated. A city must get at least 50 points from the criteria including 59 subjects; in other words, it must fulfil $50 \%$ of the criteria providing that it should fulfil at least one condition in each group to be accepted as a member. The next stage includes application to the national cittaslow authority. After the approval, the application is delivered to the International Cittaslow Union in Orvieto, a city in Italy, and if the candidate city fulfils the necessary criteria and achieves presenting concrete steps and plans, it deserves to be a cittaslow. Each city can apply for a new examination after four years. The process of the application to cittaslow is indicated below (Cittaslow Turkey, 2013).

\section{Application Letter}

An application letter which explains the city's membership in Cittaslow Union must be written addressing International Cittaslow Presidential. In this application letter, the description of the city (history, topography, population, and the features of the city, etc.), the reasons for application to Cittaslow network (the concern about cittaslow, etc.), which Cittaslow criteria it has, and the projects it carries out for fulfilling the criteria (the sides complying with Cittaslow criteria, the things that have been done and are intended to be done), and the corporate or technical identity with whom it will be in communication must be stated.

\section{Information Studies}

People must protect the Cittaslow identity and the things that have been done in this field to make the Cittaslow Project successful. What Cittaslow is, what can be done in this context, and the aim and the targets of the city as Cittaslow must all be laid down for being appropriated by people. The movement which people do not appropriate can not be successful in the long run. The public support is needed for making Cittaslow movement sustainable and taking it away from the diplomacy.

\section{Preparation of the Cittaslow Candidate File}

A city must develop a project regarding the 59 criteria stated in the Union legislation and fulfil it to be a member of Cittaslow Union. The evaluation result of the application file, which consists of the projects about Cittaslow criteria, must be more than $50 \%$. The application file consists of two parts. In the first file, there are some photos and statements about the projects done within the scope of criteria, and the second file in which there are some pictures related to the projects, the act of parliament, the formal letters will be prepared.

\section{The Delivery of the Candidate File and Grading It}

The candidate file consisting of two parts must be delivered to Cittaslow National Network in duplicate in the national language and English. The file will be examined by Cittaslow National Coordinator and authorized. During this process of examination or in any process of the application, the candidate city can be visited by the Cittaslow National Coordinator or the members of the Cittaslow National Network. If the file gets sufficient points after the examination, the files are sent to the Head Office in Italy.

\section{The Examination of the Candidate File by Head Office}

The file which has been examined from Cittaslow Turkey Network and has received a sufficient point is sent to Head Office in Italy to undergo an investigation. If the file is approved by the Head Office, the membership of the candidate city is declared in an international activity and given a certificate. The cities which have participated in the Union accept following the criteria, and this participation is certified with a certificate. All cities which deserve to use 'Snail', the logo of Cittaslow, are regularly controlled five times a year, and the continuity of the city' Cittaslow certificate is checked. When some actions and practices against the Cittaslow criterion or philosophy are determined, the cities can be excluded from the membership (Cittaslow, 2016).

Also the candidate city must pay membership fees which change depending on the population rate. The 
annual fees are 600 Euros for the cities whose population is 1.000 and less than 1.000, 750 Euros for the cities whose population is 1.000 to $5.000,2.500$ Euros for the ones whose population is 5.000 to 15.000 , and 3.500 Euros for the cities whose population is 30.000 and higher (Cittaslow, 2016). As can be seen, the application to cittaslow is an important process including bureaucratic procedure. The candidate city must carry out this process carefully and attentively. The perceptions of the city administrator are extremely important for running and dealing with the process as well as for its acceptance.

\section{Relationship between Cittaslow and Sustainability}

In literature, it is seen that the studies for the cittaslow are similar. Besides, the cittaslow is mostly discussed as a marketing activity (Karin von Zweigbergk 2009; Nillson, Sward, Widarsson and Wirell 2010). Recently, it has been seen that the cittaslow is mostly examined in terms of environment, sustainability, city plan and architecture (Radström 2005; Pink 2006; Keskin, 2010; Nillson, Sward, Widarsson and Wirell 2010). Generally, because the Cittaslow is the model of the local development, they are formed to increase the life quality of local people. Moreover, it fights against the negativeness which the globalization causes, and the studies for the saving the local culture and locality are encountered (Jones, Shears, Hillier, Comfort and Lowell 2003; Nosi and Zanni, 2004; Petrini, 2005; Knox, 2005; Loades, 2005; Parkins and Craig, 2005; Schenieder, 2008; Pink, 2009).

When the studies stated above are examined, it could be stated that there are not many studies examining the cases which occurred during the process of participation in the cittaslow movement, and the administrators' point of views for this process. In this sense, the views of the administrators about the aims of cittaslow movement and assessment of the process are discussed in this study.

The goals and criteria of cittaslow are formed based on Agenda 21; therefore, the concept of cittaslow has a close relationship with sustainability and sustainable development. Sustainable development is examined within the scope of three subjects: economic, environmental and social. Economic sustainability involves producing the necessary goods and needs in future, avoiding the approaches influential on agricultural and industrial production, and doing controlled financial borrowing in a way to pay back in future. Environmental sustainability covers such subjects as maintaining the sources in future, preferring renewable sources, and using only an efficient amount of non-renewable sources. Concepts like "protecting biological diversity, atmospheric balance and other ecosystem functions", which do not have any economic value, are included in this factor as well. The social dimension of sustainable development has been shaped basically within the framework of the concept of equality. Such subjects as human rights, social gender equality and access to health and social services are all included in social dimension (Özmete, 2010, s.81).

Cittaslow movement is based on sustainability, and the focus is on the relationship between equity, economy and environment. This model is known as 3-e model (Environment, Economy and Equity) (Knox and Mayer, 2009). The 3-e model was first put forward by Campbell (1996).

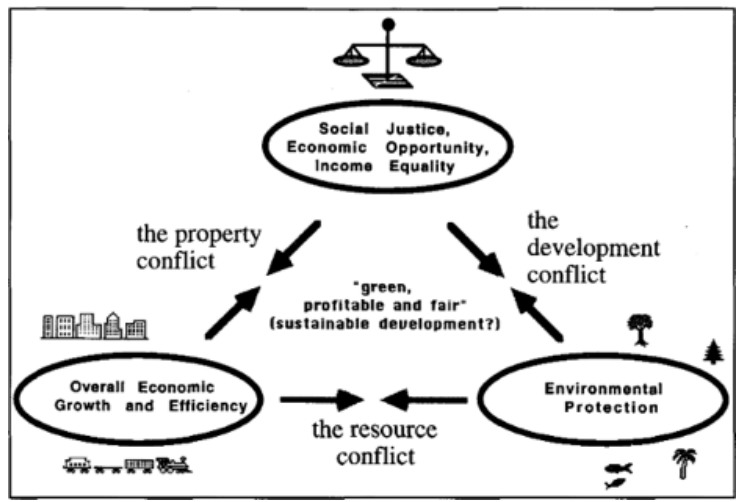

Figure 1.3-e model (Campbell, 1996) 
As can be seen in Figure 1, the 3-e model of sustainable development is combined with environmental sustainability, economic growth and social justice. However, due to the conflicts between the goals, it is not practically easy at all to find a balance between 3-e. Providing economic opportunities for a number of people could damage the environment. In this respect, it could lead to conflicts between economy and environment. An example for this could be to create employment in an area of mining in a rural area. The reason is that when we consider such a rural area totally dependent on the industry of mining, protection of species likely to be become extinct in that rural area could cause conflict between them (Campbell, 1996, s.296-312).

The cittaslow criteria are associated with the 3-e model of sustainability. "Environment" aims at protecting the environment values of alternative energy source, control of light pollution, waste management and control of air quality. Some of the criteria are related to "economic growth" in terms of local production and consumption. For instance, cittaslow movement suggests both protecting specific local products and cultural activities and developing organic agriculture and local markets in interesting and prestigious pla- ces of the city. Besides this, in order to increase local gastronomic tradition, cittaslow movement suggests encouraging planning and handcrafts in local region as well as the production attempts. The relationship of "equity" is not included directly in the list of criteria. However, because of focusing on local products and ending up with economic opportunities, it covers the criteria. Focusing on local products separates cittaslows from the definitions of sustainability. The agenda of sustainability generally focuses on use and consumption of sources, and slow food and cittaslow use the parts of sustainability related to source and environmental quality, social and cultural differences, and local products as the mediators of local economy (Mayer and Knox, 2006).

Using the methods of scientific and technological studies, Miele (2008) took the cittaslow criteria into consideration and thought that especially the cittaslow membership criteria could make it possible for each city to develop its own sustainability. Furthermore, only a few studies (Dietz, 2006; Mayer and Knox, 2006; Pink, 2008a, 2008b) established clear connection between cittaslows and the concept of sustainability.
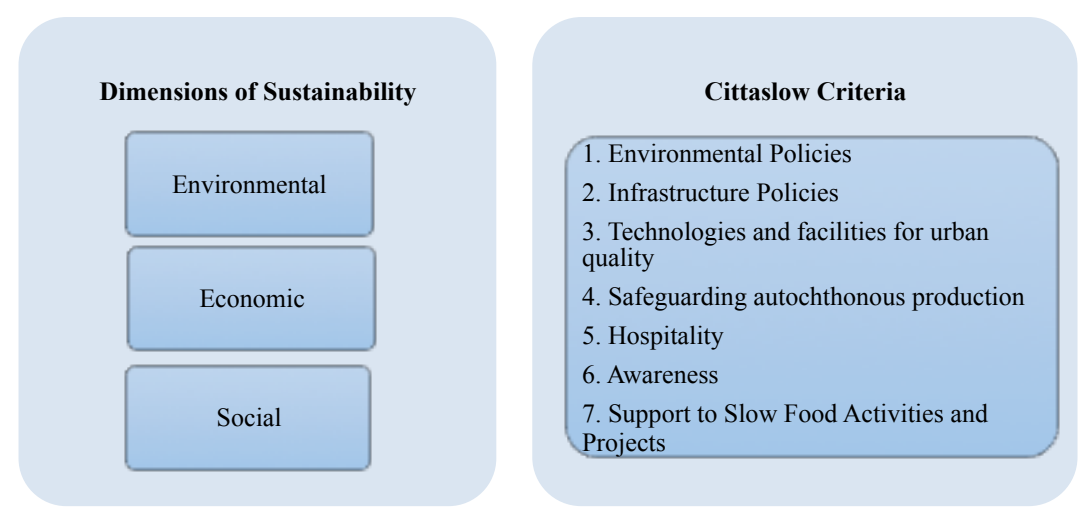

Sources: Swarbrooke, 1995; Mega and Pedersen, 1998; Cadman et.al., 1998; Knox, 2005; Radstrom, 2005; Mayer and Knox, 2006; Pink, 2008a; Miele, 2008; Heitmann et.al., 2011; Cittaslow Charter, 2013.

Figure 2. Dimensions of Sustainability and Cittaslow Criteria 
In their studies, researchers mentioned sustainability and its relationship with the concept of cittaslow. Cittaslow criteria were generally gathered under six headings. With the addition of "Extraordinary requisites" which include "Support to Slow Food activities and projects" to be executed after becoming a cittaslow, the number of headings for the criteria increased to seven (Cittaslow Charter, 2013).

When the cittaslow criteria were examined, it was seen that the environment had an important place and that the first heading for the criteria was "Environmental Criteria" (Baldemir et.al., 2013). In this respect, the priorities of cittaslows include giving importance to the quality of air, water and soil, encouraging the use of renewable energy sources appropriate to the environment, preventing the noise pollution and visual pollution, adapting themselves to such environmental management systems as Agenda 21, and supporting the spread of recycling household and industrial wastes.

Though cittaslows do not have any commercial goals, one purpose of cittaslows is to become a destination for the visitors in member cities with the help of their close relationship between cittaslows and slow food and to increase the economic sustainability of cities (Nilsson et.al., 2011). In other words, they aim at providing benefits by supporting the local products and producers. Such criteria as counting the number of products specific to the town and supporting the commerce (activating the farmers and the local market) all aim at supporting the economy. In this respect, the movement contributes to economic sustainability.

Some of the criteria to support local products and production which include items related to doing the necessary plannings to develop and introduce organic agriculture and to preparing the quality certificates for the products manufactured by local tradesmen involve social and cultural dimensions. Criteria such as developing programs for the protection of traditional professions and handcrafts which are likely to become extinct and supporting and preserving local cultural activities support local culture and socialization. In addition, with the cooperation of slow food, use of organic, local and specific products in catering services of schools and use of special-recipe gastronomic products which are likely to become extinct contribute to the city in terms of social sustainability.
The social dimensions of sustainability are taken into account in cittaslow criteria. In this respect, there are also other criteria such as informing tourists, using international tourism signs and touristic travel guidance in historical centers, preparing a slow travel guidance for the city (websites, leaflets, and so on), making touristic enterprises, tradesmen and prices transparent, and developing programs to help the public understand the life philosophy gradually.

\section{Methodology}

In this study, the purpose is to examine the administrator perceptions in terms of the stage of the application to cittaslow movement and participation, providing the necessary compulsory conditions, and the contributions which the movement will make in future. In the study, the questionnaire technique was used as a data collection tool. The population was made up of the cittaslow administrators taken from the International Cittaslow Network.

The survey was applied to the administrators in City General Assembly meeting which was in Seferihisar in 2013. For the face-to-face survey which was conducted in June 6-9, 2013 in Seferihisar, 46 administrators were reached. The other administrators were reached in July, August, and September via email, and consequently, a total of 24 administrators replied. In the study, among 167 cittaslow administrators, only 70 of them were reached. Table 2 presents the distribution of the cittaslow administrators participating in the study with respect to countries.

The survey which was applied in the study consists of three parts. In the first part, there are 9 questions which are the statements for determining the demographic attributes of the administrators. In the second part, there are 6 questions for the cittaslow criteria, and there are 7 questions for the process of cittaslow application in the third part. The statements in the third and fourth part were prepared according to the 5 point Likert scale (1. Strongly agree, 2. Agree, 3. Neither agree nor disagree, 4 . Disagree, 5. Strongly disagree). In the part in which there are demographic questions, there are questions related the administrators' gender, age (Yllmazer, 2005), educational status, year of duty (Yilmazer, 2005), how they have been informed about cittaslow, time of application and approval. The questions in the second part, were pre- 
Table 2. Cittaslow Administrators Participating in the Study

\begin{tabular}{lc}
\hline Country & $\begin{array}{c}\text { Number of } \\
\text { Participants }\end{array}$ \\
\hline South Korea & 12 \\
\hline Germany & 10 \\
\hline Poland & 9 \\
\hline Turkey & 8 \\
\hline Holland & 5 \\
\hline Italy & 3 \\
\hline France & 3 \\
\hline Belgium & 3 \\
\hline Portugal & 3 \\
\hline Austria & 2 \\
\hline Island & 2 \\
\hline Norway & 2 \\
\hline China & 1 \\
\hline Hungary & 1 \\
\hline Denmark & 1 \\
\hline Finland & 1 \\
\hline South Africa & 1 \\
\hline Sweden & 1 \\
\hline Canada & 1 \\
\hline USA & 1 \\
\hline Total & $\mathbf{7 0}$ \\
\hline
\end{tabular}

pared using the cittaslow criteria, the studies made for cittaslow partners (Radström, 2005; Mayer and Knox, 2006; Pink, 2008a; Doğutürk, 2010; Keskin, 2010; Coşar, 2013), and the expert opinions. In the part, the questions related the participation process to cittaslow and sustainability were prepared using expert opinions in addition to the literature (Radström, 2005; Mayer and Knox, 2006; Pink, 2008a; Doğutürk, 2010; Keskin, 2010; Coşar, 2013).

After creating the survey questions, the pilot scheme has been carried out. In this context, by getting the evaluations of 10 academicians who do studies in cittaslow and 8 specialists in this subject regarding the questions, the necessary corrections have been made and make them ready for the implementation. The surveys have been prepared taking into account the number and the countries of cittaslow administrators, and translating into 5 different languages. First of all, the descriptive statistics rates are calculated by evaluating the data obtained. Also in the study, as a result of reliability analysis applied to statements explaining the independent variable, Cronbach Alpha coefficient has been calculated as 0,693 . In addition to the descriptive statistics; Mann-Whitney $U$ and Kruskal-Wallis $\mathrm{H}$ tests were used in the analysis of the obtained data.

In the study, as a result of the reliability analysis conducted on the statements explaining the independent variables, the Cronbach Alpha coefficient for the third part of the question form (statements regarding the cittaslow movement participation process) was calculated as 0,693 and that of the fourth part (statements regarding the dimensions of sustainability and cittaslow) as 0,915 . The reliability coefficient of the question form was found to be 0,948 . The fact that the Cronbach Alpha coefficient was in the range of $0,80-1,00$ demonstrates that the scale had a high level of reliability. In addition, field experts were asked to examine the scale for content validity (Karasar, 2005, s.151-152).

In order to see whether the dimensions of sustainability in the last part of the questionnaire form demonstrated a normal distribution or not, Shapiro Wilk W test was applied. 
Table 3. Normal Distribution Data of Dimensions of Sustainability

\begin{tabular}{llll}
\hline Dimensions of Sustainability & \multicolumn{3}{l}{ Shapiro-Wilk } \\
\hline & Statistic & $\mathbf{d f}$ & $\mathbf{p}$ \\
\hline Economic Dimension & 0,970 & 62 & $0,130^{*}$ \\
\hline Social Dimension & 0,959 & 62 & $0,039^{*}$ \\
\hline Environmental Dimension & 0,956 & 62 & $0,027^{*}$ \\
\hline General Assessment & 0,973 & 62 & $0,180^{*}$ \\
\hline
\end{tabular}

The results of Shapiro-Wilk test revealed that the $\mathrm{W}$ values were 0,130 for the dimension of economy, 0,039 for social dimension and 0,027 for the environmental dimension. All these values were found closer to the value of "0". Depending on this, it was found that the data did not have a normal distribution, and non-parametric tests were applied to analyze the data. In this respect, in cases two or fewer independent variables, Mann Whitney U test, a non-parametric alternative to t-test, was applied, while in cases of more than two independent variables, Kruskal Wallis $\mathrm{H}$ test, a non-parametric alternative to One-Way ANOVA, was conducted (Özdamar, 2011).

\section{Analysis}

The distribution regarding the sociodemographic attributes of the cittaslow administrators who have taken part in the survey is shown in Table 4 .

In the study, $72,9 \%$ of the administrators are male, and $27,1 \%$ of them are female. The age range of $30 \%$ of the participants is in $51-60$ years, of $27,1 \%$ is in $31-40$ years and the range of the participants who are under 30 is $1,4 \%$. According to the educational status of the administrators, $44,3 \%$ of them are bachelor, $11,4 \%$ of them have associate degree, $11,4 \%$ of them are high school graduate, and $2,9 \%$ of them are primary scho-

Table 4. Sociodemographic Attributes of the Cittaslow

\begin{tabular}{lll}
\hline Gender & $\mathbf{N}$ & $\mathbf{\%}$ \\
\hline Female & 19 & 27,1 \\
\hline Male & 51 & $\mathbf{7 2 , 9}$ \\
\hline Age & 1 & 1,4 \\
\hline 30 and below & 19 & 27,1 \\
\hline $31-40$ & 15 & 21,4 \\
\hline $41-50$ & 21 & $\mathbf{3 0 , 0}$ \\
\hline $51-60$ & 14 & 20,0 \\
\hline 61 and over & & \\
\hline Educational Status & 2 & 2,9 \\
\hline Primary Education & 8 & 11,4 \\
\hline High school & 31 & $\mathbf{4 4 , 3}$ \\
\hline Associate & & 41,4 \\
\hline Undergraduate & 29 & \\
\hline Postgraduate & & $\mathbf{5 1 , 4}$ \\
\hline Working time & 36 & 24,3 \\
\hline $1-5$ years & 17 & 7,1 \\
\hline 6-10 years & 5 & 5,7 \\
\hline 11-15 years & 4 & 11,5 \\
\hline 16-20 years & 8 & $\mathbf{1 0 0}$ \\
\hline 21 years and over & $\mathbf{7 0}$ & \\
\hline Total & &
\end{tabular}


ol graduate. This shows that $85,7 \%$ of them are highly trained. When examined the working time, the rate is $51,4 \%$ for those who have worked for $1-5$ years, for those having worked for $6-10$ years it is $24,3 \%$ and it is $11,5 \%$ for those having worked for 21 years and more. This shows that, $75,7 \%$ of the administrators are experienced for 10 years or less. The way how the participants have been informed about Cittaslow is shown in Table 5.

Table 5. The Way How the Participants Have Been Informed About Cittaslow

\begin{tabular}{|l|l|}
\hline $\begin{array}{l}\text { How Have You Been Informed About Cittaslow? } \\
\text { (You may choose more than one option) }\end{array}$ & $\mathbf{n}$ \\
\hline The administrators of province having Cittaslow title & 30 \\
\hline National broadcast & 13 \\
\hline The administrators of province who do not have Cittaslow title & 10 \\
\hline International broadcast & 8 \\
\hline Local people & 8 \\
\hline Social media & 8 \\
\hline A visit to Cittaslow & 5 \\
\hline Coworker & 4 \\
\hline Cittaslow web sites & 4 \\
\hline Slow food movement & 4 \\
\hline Others & 7 \\
\hline
\end{tabular}

According to Table 5, most of the administrators have had information from the administrators of province having Cittaslow title (30) and from national broadcast (13). Other administrators (10), international broadcast (8), local people (8) and social media (8) follow these sources of information. When thought that social media is an inseparable part of our life, this rate is rather low. While 5 administrators have had information via visiting a cittaslow, 4 of them have had information via coworker. The other 4 have had information via cittaslow web sites while 4 of them have had information via slow food movement. The preparation process before application to Cittaslow is shown in Table 6.

Table 6. Cittaslow Preparation Process

\begin{tabular}{|l|l|l|}
\hline $\begin{array}{l}\text { Cittaslow Preparation } \\
\text { Process }\end{array}$ & $\mathbf{n}$ & $\mathbf{\%}$ \\
\hline 0 -12 months & 38 & 54,2 \\
\hline 13-24 months & 21 & 30 \\
\hline 25- 36 months & 11 & 15,7 \\
\hline
\end{tabular}

When examined, it is understood that the process of the candidateship doesn't extend back a long process. $54,2 \%$ of the administrators have a preparation process in the range of $0-12$ years. $30 \%$ of them have undergone a process in the range of 13-24 years. In other words, $85 \%$ of the administrators have finished their preparation process in 2 years and less. 15,7\% of them have undergone a preparation process between the range of 2 years and more and 3 years. The findings related average and Standard deviation of the statements for the administrators' perceptions to objectives of the Cittaslow Movement are shown in Table 7. 
Table 7. Administrators' Perceptions to Objectives of the Cittaslow Movement

\begin{tabular}{|c|c|c|c|c|}
\hline \multirow{2}{*}{$\begin{array}{l}\text { Cittaslow Objectives } \\
\text { (Significance Level) }\end{array}$} & \multicolumn{4}{|c|}{ Distributions } \\
\hline & $\mathbf{n}$ & $\%$ & $\mathbf{M}$ & SD \\
\hline \multirow{6}{*}{ 1.Sustainable Destination Marketing } & 17 & 24,3 & \multirow[t]{6}{*}{4,34} & \multirow[t]{6}{*}{1,54} \\
\hline & 24 & 34,3 & & \\
\hline & 6 & 8,6 & & \\
\hline & 9 & 12,9 & & \\
\hline & 7 & 10,0 & & \\
\hline & 4 & 5,7 & & \\
\hline \multirow{6}{*}{$\begin{array}{l}\text { 2. Protecting the Destination's Historic } \\
\text { and Architectural Texture }\end{array}$} & 17 & 24,3 & \multirow[t]{6}{*}{4,13} & \multirow[t]{6}{*}{1,60} \\
\hline & 17 & 24,3 & & \\
\hline & 9 & 12,9 & & \\
\hline & 10 & 14,3 & & \\
\hline & 10 & 14,3 & & \\
\hline & 4 & 5,7 & & \\
\hline \multirow[t]{6}{*}{ 3.Improving the Tourism } & 15 & 21,4 & \multirow[t]{6}{*}{3,76} & \multirow[t]{6}{*}{1,64} \\
\hline & 9 & 12,9 & & \\
\hline & 11 & 15,7 & & \\
\hline & 15 & 21,4 & & \\
\hline & 11 & 15,7 & & \\
\hline & 6 & 8,6 & & \\
\hline \multirow[t]{6}{*}{ 4.Saving the Environment } & 8 & 11,4 & \multirow[t]{6}{*}{3,52} & \multirow[t]{6}{*}{1,44} \\
\hline & 7 & 10,0 & & \\
\hline & 21 & 30,0 & & \\
\hline & 13 & 18,6 & & \\
\hline & 12 & 17,1 & & \\
\hline & 6 & 8,6 & & \\
\hline \multirow[t]{6}{*}{ 5.Providing Regional Development } & 3 & 4,3 & \multirow[t]{6}{*}{2,71} & \multirow[t]{6}{*}{1,54} \\
\hline & 7 & 10,0 & & \\
\hline & 13 & 18,6 & & \\
\hline & 9 & 12,9 & & \\
\hline & 15 & 21,4 & & \\
\hline & 20 & 28,6 & & \\
\hline \multirow[t]{7}{*}{ 6.Improving the City Quality } & 7 & 10,0 & \multirow[t]{6}{*}{2,52} & \multirow[t]{6}{*}{1,68} \\
\hline & 3 & 4,3 & & \\
\hline & 7 & 10,0 & & \\
\hline & 11 & 15,7 & & \\
\hline & 12 & 17,1 & & \\
\hline & 27 & 38,6 & & \\
\hline & 67 & 95,7 & & \\
\hline
\end{tabular}

1: Strongly Disagree , 5: Strongly Agree, $\mathrm{n}=67$

Among the objectives, the objective 'Marketing the Destination Sustainably' has been seen the most important one by 41 administrators $(58,6 \%)$. The average which is 4,34 shows that the opinions of the models who state an opinion are quite homogeneous. 34 administrators $(48,6 \%)$ think that the objective 'Protecting the Destination's Historic and Architectural Texture' is of secondary importance. In order of priorities, 'Improving the Tourism' (34,3\%), 'Saving the Environment" (21,4\%), "Providing Regional Development" (15,7\%), and "Improving the Quality of the City" respectively follow the other two objectives. 3 administrators have not stated any opinion regarding each six option. The opinions of the administrators' related the difficulty level of Cittaslow criteria are shown in Table 8. 
Table 8. The Perceptions of the Administrators' Related Cittaslow Criteria

\begin{tabular}{|c|c|c|c|c|}
\hline \multirow{2}{*}{$\begin{array}{l}\text { Cittaslow Criteria } \\
\text { (Level of Difficulty) }\end{array}$} & \multicolumn{4}{|c|}{ Distributions } \\
\hline & $n$ & $\%$ & $\mathbf{M}$ & SD \\
\hline \multirow[t]{7}{*}{ 1. Infrastructure Policies } & 17 & 24,3 & \multirow[t]{7}{*}{4,57} & \multirow[t]{7}{*}{2,11} \\
\hline & 10 & 14,3 & & \\
\hline & 12 & 17,1 & & \\
\hline & 6 & 8,6 & & \\
\hline & 5 & 7,1 & & \\
\hline & 8 & 11,4 & & \\
\hline & 8 & 11,4 & & \\
\hline \multirow{7}{*}{ 2.Awareness } & 19 & 27,1 & \multirow[t]{7}{*}{4,56} & \multirow[t]{7}{*}{2,12} \\
\hline & 7 & 10,0 & & \\
\hline & 11 & 15,7 & & \\
\hline & 7 & 10,0 & & \\
\hline & 5 & 7,1 & & \\
\hline & 11 & 15,7 & & \\
\hline & 6 & 8,6 & & \\
\hline \multirow[t]{7}{*}{ 3.Support to Slow Food activities and } & 12 & 17,1 & \multirow[t]{7}{*}{4,53} & \multirow[t]{7}{*}{1,90} \\
\hline & 16 & 22,9 & & \\
\hline & 5 & 7,1 & & \\
\hline & 10 & 14,3 & & \\
\hline & 13 & 18,6 & & \\
\hline & 5 & 7,1 & & \\
\hline & 5 & 7,1 & & \\
\hline \multirow[t]{7}{*}{ 4. Environmental Policies } & 6 & 8,6 & \multirow[t]{7}{*}{3,95} & \multirow[t]{7}{*}{1,91} \\
\hline & 10 & 14,3 & & \\
\hline & 14 & 20,0 & & \\
\hline & 10 & 14,3 & & \\
\hline & 6 & 8,6 & & \\
\hline & 11 & 15,7 & & \\
\hline & 9 & 12,9 & & \\
\hline \multirow{7}{*}{$\begin{array}{l}\text { 5.Technologies and facilities for urban } \\
\text { quality }\end{array}$} & 4 & 5,7 & \multirow[t]{7}{*}{3,93} & \multirow[t]{7}{*}{1,78} \\
\hline & 13 & 18,6 & & \\
\hline & 10 & 14,3 & & \\
\hline & 9 & 12,9 & & \\
\hline & 15 & 21,4 & & \\
\hline & 8 & 11,4 & & \\
\hline & 7 & 10,0 & & \\
\hline \multirow{7}{*}{$\begin{array}{l}\text { 6.Safeguarding } \\
\text { production }\end{array}$} & 3 & 4,3 & \multirow[t]{7}{*}{3,33} & \multirow[t]{7}{*}{1,57} \\
\hline & 3 & 4,3 & & \\
\hline & 8 & 11,4 & & \\
\hline & 15 & 21,4 & & \\
\hline & 15 & 21,4 & & \\
\hline & 14 & 20,0 & & \\
\hline & 8 & 11,4 & & \\
\hline \multirow[t]{8}{*}{ 7.Hospitality } & 5 & 7,1 & 3,07 & 2,03 \\
\hline & 6 & 8,6 & & \\
\hline & 6 & 8,6 & & \\
\hline & 10 & 14,3 & & \\
\hline & 7 & 10,0 & & \\
\hline & 9 & 12,9 & & \\
\hline & 23 & 32,9 & & \\
\hline & 67 & 95,7 & & \\
\hline
\end{tabular}

1: Strongly Disagree, 5 : Strongly Agree, $n=67$ 
According to the Table 8, support to Slow Food activities and projects is seen as the most difficult criteria. The highest percentage belongs to the criteria of infrastructure $(38,6 \%)$ and awareness $(37,1 \%)$. Technologies and facilities for urban quality and criteria of environment follow these criteria with the fourth and fifth difficulty level. Hospitality (15,7\%) and safeguarding autochthonous production $(8,6 \%)$ are seen the easiest criteria.

In Table 9, the answers of the administrators related the process of being a Cittaslow. There are questions related the applicability of the Cittaslow to a larger city with the opinions, support and education of the local people in the process of being a Cittaslow.
In the process of being a cittaslow, while $51,4 \%$ of the administrators got the local people's opinion partly, $42,9 \%$ of them got the local people's opinion completely. Also 52,9\% of the administrators were supported by the local people while $42,9 \%$ of them were partly supported by the local people. $44,3 \%$ of the administrators trained the local people related the subject. While $35,7 \%$ and $30 \%$ of the administrators have stated that the cittaslow movement can be applied in larger cities, $34,3 \%$ of them have stated that it can not be.

In Table 10, there are finding related to the average and standard deviation of the administrators' opinions regarding the process of participation in cittaslow network.

Table 9. The Answers of the Administrators Related the Process of Being a Cittaslow

\begin{tabular}{|c|c|c|c|c|c|}
\hline \multirow[t]{2}{*}{ The Process Of Being a Cittaslow } & & \multicolumn{4}{|c|}{ Distributions } \\
\hline & & $\mathbf{n}$ & $\%$ & $\mathbf{M}$ & SD \\
\hline \multirow[t]{3}{*}{ The Opinions of The Local People } & Yes & 30 & 42,9 & \multirow[t]{3}{*}{2,08} & \multirow[t]{3}{*}{97} \\
\hline & No & 4 & 5,7 & & \\
\hline & Partly & 36 & 51,4 & & \\
\hline \multirow[t]{3}{*}{ The Support of The Local People } & Yes & 37 & 52,9 & \multirow[t]{3}{*}{1,90} & \multirow[t]{3}{*}{,98 } \\
\hline & No & 3 & 4,3 & & \\
\hline & Partly & 30 & 42,9 & & \\
\hline \multirow[t]{3}{*}{ The Education of The Local People } & Yes & 31 & 44,3 & \multirow[t]{3}{*}{1,92} & \multirow[t]{3}{*}{,90 } \\
\hline & No & 13 & 18,6 & & \\
\hline & Partly & 26 & 37,1 & & \\
\hline \multirow{3}{*}{$\begin{array}{l}\text { Applicability of Cittaslow to Larger } \\
\text { Cities }\end{array}$} & Yes & 21 & 30,0 & \multirow[t]{3}{*}{2,05} & \multirow[t]{3}{*}{81} \\
\hline & No & 24 & 34,3 & & \\
\hline & Partly & 25 & 35,7 & & \\
\hline
\end{tabular}

Table 10. Questions Related to the Process of Participation in Cittaslow Network

\begin{tabular}{|c|c|c|c|}
\hline Statements & $\mathbf{n}$ & $\mathbf{M}$ & SD \\
\hline $\begin{array}{l}\text { 1. The criteria needed for participation in Cittaslow network should show flexibility according to } \\
\text { each region's own structure. }\end{array}$ & 70 & 3,38 & 1,20 \\
\hline 2. The application fee paid for the participation in Cittaslow network is high & 70 & 3,22 & 1,16 \\
\hline 3. In the process of participation in Cittaslow network, the local people gave the most support. & 70 & 2,98 & 1,10 \\
\hline 4. In the process of participation in Cittaslow network, the visitors gave the most support. & 70 & 2,95 & 95 \\
\hline 5. The bureaucratic procedure in the process of participation in Cittaslow network takes a long time. & 70 & 2,91 & 1,09 \\
\hline 6. In the process of participation in Cittaslow network, the local business gave the most support. & 70 & 2,90 & 90 \\
\hline 7. There is a lack of knowledge about the participation in Cittaslow network. & 70 & 2,81 & 1,14 \\
\hline
\end{tabular}


According to this Table, the administrators think that 'the criteria needed for participation in Cittaslow network should show flexibility according to each region's own structure' $(\overline{\mathrm{X}}=3.38)$. Also, the participation rate about the statement that fee paid for the participation in Cittaslow network is high, is quite high $(\overline{\mathrm{X}}=3.22)$. The participation rate in the statements that "In the process of participation in Cittaslow network, the local people gave the most support" ( $\bar{X}=2,98)$, 'In the process of participation in Cittaslow network, the visitors gave the most support" ( $\overline{\mathrm{X}}=2,95)$, and "In the process of participation in Cittaslow network, the local business gave the most support" $(\overline{\mathrm{X}}=2,90)$ shows that the while the local people and visitors gave support to the administrators, the local business did not. The participation rate in the statement" The bureaucratic procedure in the process of participation in Cittaslow network takes a long time" $(\overline{\mathrm{X}}=2,91)$ shows that the administrators think the bureaucratic procedure is time-consuming. The rate in the statement" There is a lack of knowledge about the participation in Cittaslow network" $(\overline{\mathrm{X}}=2,81)$ shows that there is not so much lack of knowledge during application.
Table 11 presents the findings regarding the standard deviation values and mean scores for the cittaslow administrators' views about the statements related to sustainability of cittaslows. In this part, eight of the cittaslow administrators reported that they were quite new to cittaslow and that they did not know the influence of cittaslow on sustainability, but they did not mention their level of agreement with the statements. Therefore, the responses of 62 administrators were taken into account. The statements that the administrators agreed on in the questionnaire were as follows: "The historical pattern of the city was taken under protection." (X=3,22) and "The historical pattern of the city was embraced." $(\mathrm{X}=3,19)$, "The number of cultural, art and entertainment activities in the city increased." $(\mathrm{X}=3,11)$, and "Local entrepreneurship increased" $(X=3,09)$. The statements that the administrated agreed no least were "The contribution of the nearby universities increased" $(X=2,91)$, "Public security in the city was improved" $(\mathrm{X}=2,91)$ and "The transportation facilities in the city were developed" $(\mathrm{X}=2,80)$.

Table 11. Evaluates of the Cittaslow Administrators to the Cittaslow and Sustainability

\begin{tabular}{|c|c|c|c|c|}
\hline \multicolumn{2}{|l|}{ Statements } & \multirow{2}{*}{$\begin{array}{l}\mathbf{n} \\
62\end{array}$} & \multirow{2}{*}{$\begin{array}{l}\overline{\mathbf{X}} \\
3,22\end{array}$} & \multirow{2}{*}{$\begin{array}{l}\text { Ss } \\
0,998\end{array}$} \\
\hline \multirow{16}{*}{$\begin{array}{l}\text { With the cittaslow } \\
\text { feature of our city ... }\end{array}$} & 1. The historical pattern of the city was taken under protection. & & & \\
\hline & 2. The historical pattern of the city was embraced. & 62 & 3,19 & 1,037 \\
\hline & 3. The number of cultural, art and entertainment activities in the city increased. & 62 & 3,11 & 1,160 \\
\hline & 4. Local entrepreneurship increased. & 62 & 3,09 & 0,881 \\
\hline & 5. The infrastructure problems of the city decreased. & 62 & 3,04 & 1,031 \\
\hline & 6. The city became attractive for investors. & 62 & 3,03 & 0,922 \\
\hline & 7. The public's awareness of the environment was raised. & 62 & 3,03 & 1,100 \\
\hline & 8. The corporates became more sensitive to the environment. & 62 & 3,01 & 0,877 \\
\hline & 9. The number of social responsibility projects increased. & 62 & 3,01 & 0,983 \\
\hline & 10. Planned development started in the study. & 62 & 3,01 & 0,966 \\
\hline & 11. The number of local suppliers increased. & 62 & 3,01 & 0,949 \\
\hline & 12. The number of female entrepreneurs increased. & 62 & 3,00 & 0,868 \\
\hline & 13. The city provided competitive advantage. & 62 & 3,00 & 1,116 \\
\hline & 14. The contribution of the nearby universities to the city increased. & 62 & 2,91 & 1,029 \\
\hline & 15. Public security in the city was improved. & 62 & 2,91 & 0,731 \\
\hline & 16. The transportation facilities in the city were developed. & 62 & 2,80 & 0,902 \\
\hline
\end{tabular}

1: I Completely Disagree, 5: I Completely Agree; $n=62$ 
Table 12. Results of the Mann-Whitney U test: Administrators' Evaluations of Cittaslows in Terms of Gender and Sustainability

\begin{tabular}{|c|c|c|c|c|c|c|}
\hline Dimensions & Gender & $\mathbf{n}$ & $\begin{array}{l}\text { Mean } \\
\text { Rank }\end{array}$ & $\begin{array}{l}\text { Sum of } \\
\text { Ranks }\end{array}$ & $\mathbf{U}$ & $\mathbf{p}$ \\
\hline \multirow{2}{*}{$\begin{array}{l}\text { Environmental } \\
\text { Dimension }\end{array}$} & Female & 17 & 37,38 & 635,50 & \multirow[b]{2}{*}{282,500} & \multirow[b]{2}{*}{0,113} \\
\hline & Male & 45 & 29,28 & 1317,50 & & \\
\hline \multirow{2}{*}{ Economic Dimension } & Female & 17 & 38,00 & 646,00 & \multirow{2}{*}{272,000} & \multirow{2}{*}{0,080} \\
\hline & Male & 45 & 29,04 & 1307,00 & & \\
\hline \multirow{2}{*}{ Social Dimension } & Female & 17 & 39,74 & 675,50 & \multirow{2}{*}{242,500} & \multirow{2}{*}{$0,026^{*}$} \\
\hline & Male & 45 & 28,39 & 1277,50 & & \\
\hline \multirow{2}{*}{$\begin{array}{l}\text { General } \\
\text { Sustainability }\end{array}$} & Female & 17 & 38,82 & 660,00 & \multirow{2}{*}{258,000} & \multirow{2}{*}{$0,049^{*}$} \\
\hline & Male & 45 & 28,73 & 1293,00 & & \\
\hline
\end{tabular}

${ }^{*}: \mathrm{p}<0,05 ; \mathrm{n}: 62$

When the results of Mann-Whitney $U$ test were examined (Table 12), it was seen that the variable of gender did not cause and significant difference in such dimensions of sustainability as environmental dimension and economic dimension ( $\mathrm{p}>0.05)$. In this respect, both the female and male administrators could be said to have similar views. On the other hand, there was a significant difference in terms of Social Di- mension $\left(0,026^{*}\right)$ and General Sustainability $\left(0,049^{*}\right)$ $(\mathrm{p}<0,05)$. However, when the rank mean scores for all the sub-dimensions were taken into account, it was found that the mean scores of the female administrators were higher than those of the male administrators. This result demonstrates that the female administrators had more positive perceptions regarding the influence of cittaslows on sustainability.

\begin{tabular}{|c|c|c|c|c|c|c|}
\hline Dimensions & Age & $\mathbf{N}$ & $\begin{array}{l}\text { Mean } \\
\text { Rank }\end{array}$ & sd & $\mathbf{x}^{2}$ & p \\
\hline \multirow{4}{*}{$\begin{array}{l}\text { Environmental } \\
\text { Dimension }\end{array}$} & $31-40$ & 19 & 35,74 & \multirow{4}{*}{3} & \multirow{4}{*}{1,075} & \multirow{4}{*}{0,651} \\
\hline & $41-50$ & 14 & 30,79 & & & \\
\hline & $51-60$ & 17 & 28,59 & & & \\
\hline & $61+$ & 12 & 29,75 & & & \\
\hline \multirow{4}{*}{ Economic Dimension } & $31-40$ & 19 & 42,66 & \multirow{4}{*}{3} & \multirow{4}{*}{10,921} & \multirow{4}{*}{$0,007^{*}$} \\
\hline & $41-50$ & 14 & 29,11 & & & \\
\hline & $51-60$ & 17 & 22,44 & & & \\
\hline & $61+$ & 12 & 29,46 & & & \\
\hline \multirow{4}{*}{ Social Dimension } & $31-40$ & 19 & 36,16 & \multirow{4}{*}{3} & \multirow{4}{*}{2,367} & \multirow{4}{*}{0,400} \\
\hline & $41-50$ & 14 & 30,64 & & & \\
\hline & $51-60$ & 17 & 26,06 & & & \\
\hline & $61+$ & 12 & 32,83 & & & \\
\hline \multirow{4}{*}{$\begin{array}{l}\text { General } \\
\text { Sustainability }\end{array}$} & $31-40$ & 19 & 38,21 & \multirow{4}{*}{3} & \multirow{4}{*}{3,711} & \multirow{4}{*}{0,198} \\
\hline & $41-50$ & 14 & 30,79 & & & \\
\hline & $51-60$ & 17 & 25,38 & & & \\
\hline & $61+$ & 12 & 30,38 & & & \\
\hline
\end{tabular}


As can be seen in Table above, the administrators' ages did not cause any difference with respect to the dimensions of the social dimension and general sustainability ( $p>0.05)$, while there was a statistically significant difference in terms of economic dimension of sustainability $\left(0,007^{*}\right)$. Accordingly, the administrators aged between 31 and 40 agreed more on the statements regarding the economic dimension of sustainability and were more sensitive to these statements than those from the other age groups (41-50, 51-60, 61 and older).

In addition, the tests revealed that the administrators' views did not cause any significant difference $(\mathrm{p}<0.05)$ in such sub-dimensions of sustainability as environmental dimension, economic dimension and social dimension as well as in the dimension of general sustainability in terms of the year of becoming a cittaslow, the cittaslow administrators' experience in management and their educational backgrounds.

\section{Conclusion and Suggestions}

In this study which aims at evaluating the perceptions of the administrators related to Cittaslow network, application process and sustainability, the perceptions of the administrators related to the subject are tried to be identified. It has been found that the Cittaslow administrators are generally male, middle aged, bachelors, and have 1-10 years experiences. It is seen that the administrators generally get information from the administrators of province having Cittaslow title and national broadcast. This result shows that the national broadcast for cittaslow movement should be enhanced. Also, the cittaslow administrators should give information to the candidate administrators. It has been understood that few of the administrators get information via social media and the other means. This shows that there is not enough information about Cittaslow network in social media, TV, and internet. On the other hand, slow food which constitutes the basis of the cittaslow and aims to maintain gastronomic traditions is used at least as information source. This shows slow food is not understood literally and can not find a place in practice.

Considering the preparation process, most of them transfer from preparation process to application process. This shows that it is deceptive that the application and acceptance process is long. In this context, it states that the cittaslow can get ready for the Cittaslow network in a year by giving importance their own features, and this is an important result for the candidate cities which want to apply to Cittaslow network.

Marketing the destination as sustained, saving the destination's historical and architectural texture, improving the tourism are the first three important objects of Cittaslow. This result shows that administrators' perceptions and literature are coherent (Dietz, 2006; Mayer and Knox, 2006; Pink, 2008a, 2008b). It is seen that people who participate in tourism activities in recent years is consisting of a demand for particularly undisturbed natural resources, where the company is sensitive to the environment and the historical and cultural structure of the protected areas. With this change tourist set aside the classical concept of sea-sand-sun and turn to destinations which offer alternative tourism (Sezgin and Ünüvar, 2011). Although there is no intention of developing tourism cittaslow could be interpreted as a useful strategy for tourism. Complying with cittaslow criteria is damaged to the environment in the minimal way from tourist activities.

In the process of being Cittaslow, most of the administrators have trained the local people and consequently, they have taken support from the local people. This result shows that local people participation is vital for the cittaslow movement. In the literature, the work done for local people seem to confirm this (Petrini and Padovani, 2011; Andarabi, 2012; Coşar, 2013; Çakıcı et. al., 2013). The criteria "Awareness" is the most obvious indicator of the importance of the local people for the movement. Consequently, it is important the participation and education of local people.

While the administrators state that the Cittaslow network can be applied in larger cities, one third of them state that it can not. This result is consistent with the results of studies in the literature. In the literature, it can be applied by making some additions to the criteria and carry out the movement to the population greater the 50,000 cities (Keskin, 2010; Doğutürk, 2010). On the other hand some managers stated that performing the movement in the larger cities is impossible. It seems that this could be supported not only because of failure to take the control in bigger cities but also because of loss of movement. 
There is no any lack of information during the application, while they have taken support from the local people and visitors, they have not taken any from the local business, and the bureaucratic procedure is very time consuming. The cities which joined in the movement have got to study to raise awareness of people, and to popularize the movement.

When the administrators' evaluations regarding the cittaslow criteria were examined, it could be stated that it was the most difficult criterion since the infrastructure criteria included several fundamental changes in terms of the improvement and redesign of the city. The second most difficult criterion, the awareness criteria, covers the public's participation in the movement and the development of cittaslow and slow food projects. In this respect, involvement of the local public in the movement is considered to be important and difficult for the executors. The third most difficult criterion is the criterion of support to slow food activities and projects. This criterion includes the taste trainings given at schools and the application of projects supporting the protection of products and species that are likely to become extinct. According to the administrators, the application of such big projects and changes seems to be difficult. The criterion considered by the administrators to be the easiest is hospitality. The fact the criterion of hospitality is the easiest one could be said to be due to the fact that the local public are friendly towards visitors and are conscious of the importance of tourism. When these criteria are evaluated as a whole, actually, the sub-criteria found in each main criterion are in interaction with the ones found in other main criteria or with those found in the same criterion (Baldemir et.al., 2013). This result is important since it acts as guidance for administrators willing to become cittaslows.

Cittaslow administrators state that the criteria needed should show flexibility in terms of their own structure. However, in such a case, a standardization like a cittaslow movement will not be meaningful. On the other hand, one of the renovations brought about by the new criterion system updated in 2014 is the authorization given to the national networks to add a criterion. All countries will be able to add a national criterion in a way not to exceed $\% 20$ of the score of the criterion heading in line with their own conditions (Cittaslow Turkey, 2016).
The suggestions put forward in the study actually provide local administrators with practical clues besides academic field. Therefore, in addition to the contribution of the study to the related literature, it is also expected to act as guidance for local administrators. Depending on the results and findings obtained, the following suggestions could be put forward;

- For the development of the cittaslow movement, the private sector, non-governmental organizations, local enterprises, local public and universities should all act effectively together.

- With the help of effective communication between cittaslow administrators, national publications, and rapid communication devices and the rapidly-developing Internet and social media, administrators willing to become cittaslows, local enterprises and the local public should be provided with the flow of information, and the individuals' consciousness of cittaslow and their levels of education should be increased.

- The administrators of cities nominated to become cittaslows should prepare a plan appropriate to their own destinations and take action accordingly. More consultancies should be given to the administrators on the subjects such as criteria of infrastructure, awareness, support to slow food activities and projects by the either general management or cittaslow national or international union.

- Cittaslow administrators are supposed to make their destinations sustainable in line with the cittaslow criteria and to make the cittaslow movement sustainable without seeking for any economic advantage or without making any decisions in a way to influence the natural structure of the destination. In this respect, in cooperation with the government and local administration, the necessary precautions should be taken to prevent the construction of secondary houses or hotels that will ruin the cittaslow movement. Also, housing tourism appropriate to the logic of cittaslow, home hostels and touristic enterprises appropriate to the natural structure of the region should be organized, and the local public and the local enterprises should be allowed to make the maximum benefit from this. 
- In order to help cittaslows introduce themselves, local bazars should be established to display local products and to feature the locality of cittaslows.

- The necessary plans should be prepared to increase the gastronomic traditions for the cities participating in cittaslow movement, and activities should be carried out to support the use of organic and local products in the catering services in the cittaslow. In this respect, with the slow food cooperation, programs should be developed in relation to trainings to be given at schools on dieting and tasting. Also, use and production of special-recipe gastronomic products likely to become extinct should be supported to contribute both to the application of Slow Food Movement in cittaslows and to social sustainability.

- As is known, cittaslows are defined as cities which do not have any traffic and fast living conditions. In this respect, the tools supporting public transportation in the city should be provided, and the public as well as tourists should be encouraged to use them. For example, the prominent factors of the city should be thematized, and public transportation vehicles should be prepared. These vehicles should be presented to the public and visitors' use. Moreover, use of alternative transportation vehicles like bicycles should be encouraged.

\section{References}

Cittaslow, (2016). Association. Retrieved from http:// www.cittaslow.org/section/association.

Cittaslow Charter, (2013). Retrieved from http://www. cittaslow.org/download/DocumentiUfficiali/2009/ newcharter[1].pdf

Cittaslow Turkey, (2016). Retrieved from http://www. cittaslowturkiye.org.

Coşar, Y. (2013). Yavaş Şehir (Cittaslow) Olgusunun Turist Davranışları ve Yerel Halkın Kentsel Yaşam Kalitesi Algısına Etkileri. (Yayımlanmamış doktora tezi). Dokuz Eylül Üniversitesi/ Sosyal Bilimler Enstitüsü, İzmir.
Dietz, A. (2006). Citta'slow - das gute Leben. Kulturelles Erbe, Nachhaltigkeit und Lebensqualita" $t$ in Kleinsta"dten. Magisterarbeit: Universitat Tubingen.

Doğutürk, G. (2010). Mimari ve Yaşam Kalitesi Bağlamında Yavaş Şehir Hareketi ve Seferihisar Örneği. (Yayımlanmamış yüksek lisans tezi). Mimar Sinan Güzel Sanatlar Üniversitesi/ Fen Bilimleri Enstitüsü, İstanbul.

Heitmann, S., Robinson, P. \& Povey, G. (2011). Slow food, slow cities and slow tourism. S. H. P. Robinson \& S. P. Heitmann (Eds.), In Research themes for tourism (pp. 114-127). Wallingford: CAB International.

Jones, P., Shears, P., Hillier, D., Comfort, D., \& Lowell, J. (2003). Return to Traditional Values? A Case Study of Slow Food. British Food Journal, 105(4/5), 297 304.

Keskin, E. B. (2010). Sürdürülebilir Kent Kavramına Farklı Bir Bakış Olarak Yavaş Şehirler (Cittaslow): Seferihisar Örneği. (Yayımlanmamış yüksek lisans tezi). Dumlupınar Üniversitesi/Sosyal Bilimler Enstitüsü, Kütahya.

Knox, P. L. (2005). Creating Ordinary Places: Slow Cities in a Fast World. Journal of Urban Design, 10 (1), 1-11.

Kozak, A., M. \& Aksöz, E. O. (2012). Eskişehir İli Seyitgazi İlçe Merkezinin Sakin Şehir (Cittaslow) Hareketi Kapsamında Değerlendirilmesi. (BAP projesi). Anadolu Üniversitesi/ Proje birimi, Eskişehir.

Loades, C.M. (2005). Tempo Giusto: Slow Cities and the Revitalization of Locality In The Age of Globalization, Institute of Social Anthropology. (Yayınlanmamış yükssek lisans tezi). Oslo Üniversitesi, Norveç.

Mayer, H. \& Knox, P. L. (2006). Slow Cities: Sustainable Places in A Fast World. Journal of Urban Affairs, 28(4), 321-334. 
Miele, Mara (2008). CittàSlow: Producing Slowness Against The Fast Life, Space and Polity, 12 (1), 135.

Nilsson, J.H., Svärd A., Widarsson Å. ve Wirell T. (2011). "Cittáslow" Eco-Gastronomic Heritage As A Tool For Destination Development, Current Issues İn Tourism, 14(4), 373-386.

Ocha, W. (2004). Briefing Notes, Cittaslow: The Slow City Movements.

Özdemir, G. (2008). Destinasyon Pazarlaması. Ankara: Detay.

Parkins, W. ve Craig G. (2006). Slow Living. New York: Oxford International Publishers.

Petrini, C. (2005). Slow Food, The Case for Taste. New York: Columbia University.

Pink, S. (2006). Cittaslow Movement, The Case Study Ludlow, UK.

Pink, S. (2008a). Re-Thinking Contemporary Activism: From Community to Emplaced Sociality. Ethnos, 73(2), 163-188.

Pink, S. (2008b). Sense and Sustainability: The Case of the Slow City Movement. Local Environment, 13(2), 95-106.
Pink, S. (2009). Urban Social Movements and Small Places: Slow Cities as Sites of Activism. City, 13(4), 451-465.

Radström, S. J. (2005). An Urban Identity Movement Rooted in the Sustainability of Place: A Case Study of Slow Cities and Their Application in Rural Manitoba. (Yayımlanmamış yüksek lisans tezi). Manitoba Üniversitesi, Kanada.

Radström, S. J. (2011). Identity: An Introduction and History of Cittàslow", Italian Journal of Planning Practice, 1(1), 90-113.

Sezgin, M. ve Ünüvar, Ş. (2011), Yavaş Şehir; Sürdürülebilirlik ve Şehir Pazarlaması Ekseninde. Konya: Çizgi.

Schneider, S. (2008). Good, Clean, Fair: The Rhetoric of the Slow Food Movement. College English, 70(4).

Yılmazer, A. (2005). Belediye Yöneticilerinin Isş Ahlakı ve Sosyal Sorumluluğa Yönelik Tutumlarının Incelenmesi: Adapazarı Büyükşehir ve Merkez Belediyesinde Bir Araştırma. (Sempozyumda sunulan bildiri). 2. Siyasette ve Yönetimde Etik, Sakarya.

Yurtseven, H. R., Kaya O. \& Harman S. (2010). Yavaş Hareketi. Ankara: Detay. 